\title{
REASONABLENESS AND THE COMMON LAW
}

\section{The Right Honourable Lord Hutton}

\section{The MacDermott Lecture 2004}

It is a great honour for me to give the MacDermott lecture this evening. When I was called to the Bar of Northern Ireland in 1954 Lord MacDermott was the Lord Chief Justice and it was an invaluable experience for me and other young barristers to appear before a judge of such great distinction who was always exacting but always fair. Listening to Lord MacDermott hearing a case, whether at first instance or in the Court of Appeal, and to his questions to counsel, I used to think that his mind was like the needle of a compass, as the opposing arguments were advanced and he listened to and considered the submissions. At first, his mind would swing a little from side to side but in due course his mind would settle steadily and inexorably on north, on the correct and just answer in law.

Lord MacDermott was a master of every branch of the law, but some of his finest judgments related to the law of negligence and it is on that subject that I would like to speak this evening and in particular on the subject of reasonableness.

Every law student knows the famous judgment of Lord Atkin in Donaghue v Stevenson in 1932, in which he stated the fundamental principle of the law of negligence:

\begin{abstract}
"You must take reasonable care to avoid acts or omissions which you can reasonably foresee would be likely to injure your neighbour. Who, then, in law is my neighbour? The answer seems to be - persons who are so closely and directly affected by my act that I ought reasonably to have them in contemplation as being so affected when I am directing my mind to the acts or omissions which are called into question."
\end{abstract}

This principle has subsequently been applied in thousands of cases determined by the courts, but one of the fundamental questions relating to the principle, which has arisen in different forms, is whether a claimant is always entitled to recover damages if he can prove that the defendant should have reasonably foreseen that his acts or omissions would be likely to injure him. Donaghue v Stevenson related to a case where, a manufacturer of a product sold the product, a bottle of ginger beer, to a consumer who claimed she was injured by it, because there was a decomposed snail in the bottle, or so it was pleaded; and in Donaghue v Stevenson it was held that the manufacturer owed a duty of care to the consumer and at the end of his judgment Lord Atkin stated that that was a proposition which no ordinary citizen would doubt because if was in accordance with sound common sense.

But the statement of principle by Lord Atkin was relied on by plaintiffs in cases far removed from the sale of a product to a consumer, and therefore the question arose whether Lord Atkin's statement was one of general application or was subject to qualifications. This question was addressed by Lord MacDermott in Gallagher v McDowell Ltd [1961] NI 26 which was a 
case where he held in the Court of Appeal that a building contractor could be liable in negligence to the wife of the tenant of a house who was injured by a defective floor which the contractor had constructed. Lord Lowry, who appeared as counsel for the building contractor, gave an amusing description of Lord MacDermott's conduct of the case in an address which he delivered in 1996 to the Irish Legal History Society:

"At the trial, supported by some reasonably strong authority, the defendants succeeded in getting the case withdrawn from the jury on the grounds of no duty owed. In the Court of Appeal, the Lord Chief Justice took up the ball and spreadeagled our defences. It reminded me of Jack Kyle's try at Ravenhill against the French. Our full-back was Cavalier v Pope, but to the cry of Donaghue v Stevenson, the chief swerved effortlessly past. When a new trial had been ordered, I turned to the defendants' experienced and enterprising solicitor, saying, "Harry, that could mean the House of Lords". He replied, "I'm not so sure. It all sounded horribly right to me."”

In his judgment, Lord MacDermott said at page 31:

"While Donaghue v Stevenson was meant to lay down a broad principle, its test of legal duty is linked to what is reasonable, and I doubt if Lord Atkin was prepared to adopt, as a matter of law, a standard of reasonableness in this connection which would open the door that had just been unlocked to its fullest extent. Apart, however, from this sort of limitation, which is inherent in the passage I have quoted, the better view is, I think, that the principle it enshrines was not meant to be applied so literally or widely as to preclude all exceptions."

This was a prescient statement which subsequent decisions have shown to be entirely sound. In Yuen Koon Yeu v Attorney General of Hong Kong, [1998] 1 AC 175, 191H Lord Keith of Kinkel said that:

"foreseeability does not of itself, and automatically, lead to a duty of care"

and in Caparo v Dickman [1990] 2 AC 605, 617H Lord Bridge of Harwich said:

"in addition to the foreseeability of damage, necessary ingredients in any situation giving rise to a duty of care are that there should exist between the party owing the duty and the party to whom it is owed a relationship characterised by the law as one of "proximity" or "neighbourhood" and that the situation should be one in which the court considers it fair, just and reasonable that the law should impose a duty of given scope upon the one party for the benefit of the other."

One of the important fields in which the courts have had to consider whether a duty of care arises under the principle stated by Lord Atkin, is where a local or public authority, or a person employed by such an authority, has a duty or power to take action which may affect the welfare of others. A serious of decisions have related to claims brought by persons who allege that they have suffered psychological or psychiatric harm because of the 
negligent way in which the local authority or one of its servants has performed a duty or exercised a power given to it by statute. A local authority which takes a child into care has a duty imposed on it by statute to look after such a child and to safeguard and promote the child's welfare, and there have been cases where the local authority has placed a child with foster parents and the foster father has sexually abused the child causing great psychological or psychiatric harm. There has been considerable debate whether a child so injured can recover damages for negligence at common law, where he can prove that the local authority was careless in placing him with such foster parents. The debate has been whether the child can recover damages at common law because the courts have held in cases such as $X$ (Minors) v Bedfordshire County Council [1995] 2 AC 633, that there is no right to sue the local authority for breach of its statutory duty itself - if the child is to succeed it must be under the common law principle of negligence.

This debate has given rise to a number of separate points. The first point is whether the neighbour relationship giving rise to the duty of care can arise where the defendant is exercising a statutory power. On this point the law has been clear for many years. It is well established that in exercising a statutory power a government department or a public or local authority may place itself in such a position to another person that it creates the relationship of neighbour giving rise to a duty to take reasonable care. The law was succinctly stated by Mason $\mathrm{J}$ in the High Court of Australia in Sutherland Shire Council v Heymen (1985) 157 CLR 424, 459:

"it has been generally accepted that, unless the statute manifests a contrary intention, a public authority which enters upon an exercise of statutory power may place itself in a relationship to members of the public which imports a common law duty to take care."

This point is illustrated in the judgment of the House of Lords in Dorset Yacht Co Ltd v Home Office [1970] AC 1004. In that case Borstal boys detained under statutory powers had been taken to an island under the control of supervision of three Borstal officers. The boys escaped and sought to leave the island by stealing a yacht which they so mishandled as to damage the plaintiff's yacht which was at anchor nearby. It was alleged that the three officers were negligent in failing to control the Borstal boys and that the Home Office was vicariously responsible for their actions. The House of Lords rejected an application by the Home Office to strike out the claim. In his judgment Lord Pearson said at page 1056D:

"Be it assumed that the defendants' officers were acting in pursuance of statutory powers (or statutory duties which must include powers) in bringing the Borstal boys to Brownsea Island to work there under the supervision and control of the defendants' officers. No complaint could be made of the defendants' officers doing that. But in doing that they had a duty to the plaintiffs as 'neighbours' to make proper exercise of the powers of supervision and control for the purpose of preventing damage to the plaintiffs as 'neighbours'."

However, the exercise of a statutory power often involves the exercise of a discretion and there has been considerable debate in the courts as to whether a claimant can sue a public or local authority for negligence in the exercise 
of a statutory discretion. This debate has involved consideration of the extent to which the principle governing judicial review of the exercise of a statutory discretion by a public or local authority is applicable to actions for negligence. In the well known case of Associated Provincial Picturehouses Ltd $\mathrm{v}$ Wednesbury Corporation (1948) 1 KB 223 Lord Greene MR stated the principle, which has been constantly applied, that a court should not intervene to set aside a decision to exercise a statutory discretion in a particular way unless the decision was so unreasonable that no reasonable authority could ever have come to it. Lord Greene made clear that when a public authority is given a discretion by Parliament it is for the authority to decide how to exercise the discretion and not the court. Leaving aside issues as to unfairness the power of the court to interfere is not as an appellate authority to override a decision of the authority, but as a judicial authority which is concerned, and concerned only, to see whether the authority has contravened the law by acting in excess of the powers which Parliament has conferred on it.

In the Dorset Yacht case, as I have stated, the House of Lords held that the Home Office could be liable for the negligence of its servants, the prison officers, notwithstanding that they had brought the boys to the island in exercise of a statutory power, but the House of Lords pointed out that in supervising the boys in the defective manner which they did, the prison officers were not acting in exercise of a discretion, to the contrary, they had been ordered to keep the boys in custody and under control but they negligently failed to carry out their orders.

However, there is a passage in the judgment of Lord Reid, although it is obiter, and a passage in the judgment of Lord Diplock, which were understood in some subsequent cases to state that there could not be an action for negligence if the act by the public authority alleged to be negligent was carried out in exercise of a statutory discretion. Lord Reid stated at page 1031A:

"Where Parliament confers a discretion . . . there may, and almost certainly will, be errors of judgment in exercising such a discretion and Parliament cannot have intended that members of the public should be entitled to sue in respect of such errors. But there must come a stage when the discretion is exercised so carelessly or unreasonably that there has been no real exercise of the discretion which Parliament has conferred. The person purporting to exercise his discretion has acted in abuse or excess of his power. Parliament cannot be supposed to have granted immunity to persons who do that."

Lord Diplock stated at page 1067G:

"over the past century the public law concept of ultra vires has replaced the civil law concept of negligence as the test of the legality, and consequently of the actionability, of acts or omissions of government departments or public authorities done in the exercise of a discretion conferred upon them by Parliament as to the means by which they are to achieve a particular public purpose. According to this concept, Parliament has entrusted to the department or authority charged with the administration of the statute the exclusive 
right to determine the particular means within the limits laid down by the statute by which its purpose can best be fulfilled. It is not the function of the court, for which it would be illsuited, to substitute its own view of the appropriate means for that of the department or authority by granting a remedy by way of a civil action at law to a private citizen adversely affected by the way in which the discretion has been exercised. Its function is confined in the first instance to deciding whether the act or omission complained of fell within the statutory limits imposed upon the department's or authority's discretion. Only if it did not, would the court have jurisdiction to determine whether or not the act or omission, not being justified by the statute, constituted an actionable infringement of the plaintiffs' rights in civil law."

These two passages were applied rigidly in some cases, irrespective of the particular circumstances of the case, so as to exclude liability for the action complained of, if the action were taken by a public or local authority or one of its servants in the exercise of a statutory discretion. This was the approach taken by the Court of Appeal in Barrett v Enfield London Borough Council [1998] QB 367. In that case the plaintiff had been placed in the care of the defendant local authority pursuant to a care order when he was ten months old and he remained in care until the age of 17 . He claimed damages for psychiatric injuries arising from the alleged negligence of the local authority. The plaintiff's main allegation was that the local authority had failed to place him for adoption, which resulted throughout the years of his childhood and youth in him having no settled home but in moving about between a number of foster parents, interspersed with periods in residential institutions. He claimed that this disturbed and unsettled life, with no firm background of family love and affection had caused him psychiatric damage. The Court of Appeal upheld a decision at first instance that the claim should be struck out as disclosing no reasonable cause of action, and one of its grounds of decision was that the local authority could not be guilty of negligence because it was acting within the ambit of its statutory discretion. Lord Woolf MR stated at page 375D:

"The complaints which go to the heart of the plaintiff's claim are all ones which involve the type of decisions which an authority has to take in order to perform its statutory role in relation to children in its care. The decision whether or not to place the child for adoption; the decision as to whether to place a child with particular foster parents; the decision whether to remove a child from a foster parent; the decisions as to the child's relationship with his mother and sister; all involve the exercise of discretion in the performance of the differing statutory responsibilities of the local authority."

Evans LJ stated at page 379G:

"the defendant cannot be held liable for breach of any putative common law duty where he has acted within the scope of his statutory responsibilities." 
And Schiemann LJ stated at page 381E:

"in so far as any of the decisions were made within the ambit of the statutory discretion given to the authority they are not actionable."

This decision was reversed by the House of Lords [2001] 2 AC 530. The House cited a passage in the judgment of Lord Reid in the Dorset Yacht case where at page 1031 he said that the Borstal system was based on the belief that it assisted the rehabilitation of trainees to give them as much freedom and responsibility as possible. Accordingly, the responsible authorities had to weigh on the one hand the public interest of protecting neighbours and their property from the depredations of escaping trainees and on the other hand the public interest of promoting rehabilitation. Therefore Lord Reid observed that there was much room for differences of opinion and errors of judgment.

A principal part of the reasoning of the House of Lords in the Barrett case was that it was necessary to appreciate that the observations of Lord Reid and Lord Diplock that there can be no action for negligence in respect of actions carried out within the ambit of a statutory discretion were made against the background of the facts of the Dorset Yacht case and in the context of the statutory discretion under consideration and that their opinion was based, in part, on the consideration that the courts were ill suited in a sphere such as Borstal training to substitute their views for the views of the Home Secretary and his officials. The underlying principle to be derived from the two relevant passages in the judgments of Lord Reid and Lord Diplock was that the courts would not permit a claim for negligence to be brought where a decision on the existence of negligence would involve the courts in considering matters of policy raising issues which they are ill equipped and ill suited to assess and where Parliament could not have intended that the courts would substitute their views for the views of ministers or officials. The House cited with approval a passage in the judgment of Mason J in Sutherland Shire Council v Heyman where he said at page 468:

"The distinction between policy and operational factors is not easy to formulate, but the dividing line between them will be observed if we recognise that a public authority is under no duty of care in relation to decisions which involve or are dictated by financial, economic, social or political factors or constraints. Thus budgetary allocations and the constraints which they entail in terms of allocation of resources cannot be made the subject of a duty of care. But it may be otherwise when the courts are called upon to apply a standard of care to action or inaction that is merely the product of administrative direction, expert or professional opinion, technical standards or general standards of reasonableness."

Accordingly, the House declined to strike out the action because at the trial the judge might not be required to weigh matters of policy involving the balancing of competing public interest or the allocation of limited financial resources and it might be that the judge, as Mason $\mathbf{J}$ put it, would only be called upon 
"to apply a standard of care to action or inaction that is merely the product of administrative direction, expert and professional opinion, technical standards or general standards of reasonableness."

In the judgment of the House in Barrett consideration was given to the earlier judgment of Lord Browne-Wilkinson in the Bedfordshire case upon which the Court of Appeal had relied. There were passages in that judgment which, if read in isolation, supported the approach taken by the Court of Appeal, but the House considered that the most important passage in Lord Browne-Wilkinson's judgment was the passage at page $748 \mathrm{G}$ where he stated:

"The alleged breaches of that duty relate for the most part to the failure to take reasonable practical steps, for example, to remove the children, to allocate a suitable social worker or to make proper investigations. The assessment by the court of such allegations would not require the court to consider policy matters which are not justiciable. They do not necessarily involve any question of the allocation of resources or the determination of general policy."

Accordingly, the House considered that that judgment did not preclude a ruling in favour of the plaintiff in Barrett.

In Caparo, in the passage that I have already cited, Lord Bridge of Harwich stated that the court will only impose a duty of care where the situation is one in which it considers it fair, just and reasonable to impose such a duty. This issue was considered both in the Bedfordshire case and in Barrett. In the Bedfordshire case the House of Lords considered a number of cases in which there were allegations that a number of local authorities had been guilty of negligence in exercise of their statutory duty to protect children and the House upheld a ruling that most of the claims should be struck out. Part of the reasoning of the House was that it would not be just and reasonable to impose a common law duty on a local authority in relation to performance of its statutory duties in relation to children because the imposition of such a duty would cut across the statutory system for the protection of children and might, in a delicate situation, make a local authority adopt a more cautious approach, to the prejudice of children. However, in the Bedfordshire case at page $749 \mathrm{G}$ Lord Browne-Wilkinson said that "the public policy consideration which has first claim on the loyalty of the law is that wrongs should be remedied." In the Barrett case the House held that there were not sufficiently potent counter-considerations to override that claim and that it would not be unjust or unreasonable to impose liability on the local authority if negligence were proved and the House expressly approved the statement of Evans LJ in the Court of Appeal at page 380A:

"I would agree that what is said to be a "policy" consideration, namely, that imposing a duty of care might lead to defensive conduct on the part of the person concerned and might require him to spend time or resources on keeping full records or otherwise providing for self-justification, if called upon to do so, should normally be a factor of little, if any, weight. If the conduct in question is of a kind which can be measured against the standards of the reasonable man, placed as the defendant 
was, then I do not see why the law in the public interest should not require those standards to be observed."

Subsequent to the decision in Barrett the Court of Appeal considered the set of circumstances to which I have earlier referred, where a plaintiff brought a claim in negligence against the local authority for placing him with foster parents where he was subjected to serious sexual abuse. Reversing a decision at first instance that the action should be struck out, the Court of Appeal held in $S$ v Gloucestershire County Council [2001] Fam 313 that the action should be allowed to proceed to trial and May LJ stated at page 337E:

"Where the failing alleged has related to a discretionary decision which is empowered by statute, the court has been hesitant to say that the exercise of the discretion was wrong so as to give rise to a cause of action unless it was plainly wrong. The intense intellectual analysis which questions of this kind engendered has been simplified by the now clear recognition that there may be circumstances in this acutely difficult area of human endeavour where an ordinary common law claim in negligence upon Caparo principles may be academically possible and, in an appropriate case, succeed in fact."

Lord MacDermott concluded his judgment in Gallagher v McDowell Ltd with these words at page 44:

"The attitude that any enlargement of the field of tortuous liability is always to be regarded as a step in the right direction is not one to be commended. Some gap between morality and law is inevitable and, if the gap is not too large, may be for the benefit of both codes. On the other hand, the changes to be expected in a progressive society call, from time to time, for such adjustments in the domain of legal responsibility as will promote justice and fair dealing."

I venture to think that Lord MacDermott would have approved the decision in Barrett and in $S \mathrm{v}$ Gloucestershire County Council and would have considered that those decisions constituted such an adjustment in the domain of legal responsibility as promoted justice and fair dealing.

Another area where there has been debate whether the principle stated by Lord Atkin should apply so as to impose liability, relates to steps which could have been taken by a highway authority to improve road safety by the painting or erecting of warning signs on a road or the removal of features on neighbouring land which obstruct the visibility of motorists. In the case of Stovin v Wise [1996] AC 923 the House of Lords divided 3-2 on the question. In that case the plaintiff was riding his motorcycle along a road when a car driven by the defendant emerged from a side road into his path and collided with him, causing him serious injuries. The driver of the car was guilty of negligence but she joined the highway authority as a third party claiming that its negligence had contributed to the accident. The junction was known by the highway authority to be a dangerous one because a bank on adjoining land restricted the view of a motorist emerging from the side road and a number of accidents had already occurred at the junction. Twelve months before the accident involving the plaintiff, a divisional surveyor of the highway authority after a site meeting accepted that the bank obstructed 
the view of a driver coming to the junction from the side road and recommended removal of part of the bank. The highway authority accepted this recommendation and proposed to the owner of the adjacent land that the bank should be removed but the owner made no response and the highway authority took no further action until the accident.

The judgments in Stovin v Wise emphasised that, in part for historical reasons, there is an important distinction between an accident which is caused by the highway falling into disrepair and an accident which may be contributed to by a failure on the part of the highway authority to erect warning signs or to remove an obstruction on adjoining land which interferes with visibility. Since 1961 Parliament has imposed an express statutory duty on highway authorities to keep the highway in repair and a user of the highway injured by reason of lack of repair can recover damages unless the highway authority proves that it had taken such care as was reasonable to secure that the relevant part of the highway was not dangerous for traffic. But there is no statutory duty to erect warning signs or to remove obstructions, although there are statutory powers to do so. In his judgment in Stovin v Wise, with which Lord Goff of Chieveley and Lord Jauncey of Tullichettle agreed, Lord Hoffmann held that the highway authority did not owe a duty of care at common law and he said at page 953D:

"In summary, therefore, I think that the minimum preconditions for basing a duty of care upon the existence of a statutory, if it can be done at all, are, first, that it would in the circumstances have been irrational not to have exercised the power, so that there was in effect a public law duty to act, and secondly, that there are exceptional grounds for holding that the policy of the statute requires compensation to be paid to persons who suffer loss because the power was not exercised."

He concluded his judgment by stating at page 958D:

"Given the fact that the British road network largely antedates the highway authorities themselves, the court is not in a position to say what an appropriate standard of improvement would be. This must be a matter for the discretion of the authority. On the other hand, denial of liability does not leave the road user unprotected. Drivers of vehicles must take the highway network as they find it. Everyone knows that there are hazardous bends, intersections and junctions. It is primarily the duty of drivers of vehicles to take due care. And if, as in the case of Mrs Wise, they do not, there is compulsory insurance to provide compensation to the victims. There is reason of policy or justice which requires the highway authority to be an additional defendant."

The first precondition in the passage at page 953D is similar to the passages from the judgments of Lord Read and Lord Diplock which I have already cited.

In his dissenting judgment, with which Lord Slynn of Hadley agreed, Lord Nicholls of Birkenhead stated that, in his opinion, that there were several features in the case which, in combination, pointed to the conclusion that it would be fair and reasonable to impose a common law duty of care. The 
features to which Lord Nicholls referred were these. First, the subject matter was physical injury. The existence of a source of danger exposes road users to a risk of serious, even fatal, injury. Second, the road authority knew of the danger. It was aware of a risk of which road users might be ignorant. Third, if the road authority had complied with its public law obligations the danger would have been removed and the accident would not have happened.

Fourth, in 1961 Parliament had abrogated the old rule which exempted the inhabitants at large and their successors from liability for non-repair of highways, and a highway authority is now liable in damages for failing to take reasonable care to keep the highway safe, but no sound distinction could be drawn between dangers on the highway itself, where the authority has a statutory duty to act, and other dangers, where there is a statutory power but not a statutory duty. The distinction would not correspond to the realities of road safety. Fifth, public law is unable to give an effective remedy if a road user is injured as a result of an authority's breach of its public law obligations. A concurrent common law duty is needed to fill the gap. Sixth, a common law duty in the case before the House would not represent an incursion into a wholly novel field. Although a highway authority does not occupy the highway, there is a certain resemblance between it and the occupier of land who can be under a positive duty to take positive action to protect his neighbours.

Seventh, a common law duty would not impose on the highway authority any more onerous obligation, so far as its behaviour was concerned, than its public law obligations. Finally, there may be cases, unlike the one under consideration, where a road user is injured by reason of a danger on the road where no other road user has been involved and there is no other road user to sue. And Lord Nicholls stated at page 941C:

"Then it does seem eminently fair and reasonable that the loss should fall on the highway authority and not the hapless road user. And if the existence of a duty of care in all cases, in the shape of a duty to act as a reasonable authority, has a salutary effect on tightening administrative procedures and avoiding another needless road tragedy this must be in the public interest."

Lord Hoffmann's majority judgment in Stovin v Wise was, of course, given before the judgments in Barrett v Enfield London Borough Council holding that the fact that a negligent action by a local authority was taken in exercise of a statutory discretion did not necessarily exclude liability for negligence at common law, and the question whether the highway authority could be liable for negligence for a danger on the road was argued for a second time before the House of Lords in the case Gorringe v Calderdale Metropolitan Borough Council in which judgments were delivered on 1 April 2004 and have not yet appeared in the law reports.

In that case on a country road in Yorkshire, the plaintiff drove her car head on into a bus. The bus was hidden behind a sharp crest in the road until just before she reached the top. When she first caught sight of the bus, a curve on the far side may have given her the impression that it was actually on her side of the road. She braked when travelling at 50 miles an hour and the wheels locked and the car skidded into the path of the bus and the plaintiff suffered very severe brain damage. There was no fault on the part of the bus 
driver who was driving with proper care when the plaintiff skidded into him. It appeared to be clear that the council were aware that there was some degree of danger at this point in the road because at some time the word "SLOW" had been painted on the road surface at a point before the crest, but this marking had disappeared, probably when the road was mended seven or eight years before. The plaintiff claimed that the council, as the highway authority, caused the accident by failing to give her proper warning of the danger involved in driving fast when she could not see what was coming. However, the House of Lords unanimously held that there was no common law duty of care on the highway authority and that the plaintiff's claim must fail.

In his judgment Lord Hoffmann stated at paragraph 17:

"Reasonable foreseeability of physical injury is the standard criterion for determining the duty of care owed by people who undertake an activity which carries a risk of injury to others. But it is insufficient to justify the imposition of liability upon someone who simply does nothing: who neither creates the risk nor undertakes to do anything to avert it. The law does recognise such duties in special circumstances: see, for example, Goldman v Hargrave [1967] 1 AC 645 on the positive duties of adjoining landowners to prevent fire or harmful matter from crossing the boundary. But the imposition of such a liability upon a highway authority through the law of negligence would be inconsistent with the well established rules which have always limited its liability at common law."

Lord Brown of Eaton-under-Heywood stated in his judgment at paragraph 103:

"There seems to me, therefore, no good reason for superimposing upon such general powers and duties as are conferred upon highway authorities a common law duty of care in respect of their exercise. Nor does it seem to me that Parliament can have intended a private law liability in damages to flow from a public law failure in the exercise of the authority's powers or the discharge of its duties. Where with regard to highways Parliament does intend users to have a remedy for damages it says so, as initially it did in 1961 and then again, by extending the section 41 duty to encompass the removal of ice and snow, in 2003. A maintenance obligation of this nature, moreover, lends itself to enforcement by way of private law action altogether more readily than a more general duty of care. Section 41 imposes comparatively well defined obligations upon authorities and, although resort to the section 58 statutory defence may complicate the litigation, that is as nothing compared to the problems, exemplified by this very case, of determining just what warnings at any particular point in the highway system are required, in effect as a matter of law, to be given. One cannot over-maintain the fabric of the public highway. Warning overload, however, is all too easily imaginable. As it is, road users tend to discount such warnings 
as are implicit in the various speed limits and other cautionary signs to which they are subject. The currency would be debased still further were highway authorities, anxious to avoid lengthy and expensive litigation of the kind Calderdale has been subjected to here, to feel obliged to multiply its street signing still further."

There are two lines of reasoning in the majority judgment in Stovin v Wise and in the judgments in Gorringe. One related to the policy reasons set out in the judgment of Lord Hoffmann in Stovin v Wise and the judgment of Lord Brown in Gorringe. The other was the recognition that both the earlier common law and the later statute law imposed no liability on a highway authority to pay damages to an injured road user because of a failure to protect him from some danger on the highway (other than a danger caused by non-repair when the law was changed by statute). The policy reasons set out in Stovin v Wise and Gorringe for not imposing common law liability are powerful ones, but in my respectful opinion the reasoning of Lord Nicholls in Stovin was also powerful, and having regard to the emphasis which the House of Lords placed on the historical background relating to the absence of liability on the part of highway authorities, I consider that the words of Lord MacDermott in Gallagher v McDowell at page 32 are again apposite and prescient because he said:

"The fact seems to be that the concept of negligence as a separate cause of action developed too late to avoid certain anomalies. The flood it begot submerged parts of the older law but it had to eddy round and leave intact other parts that derived from the forms of action and the notions of an earlier age."

As to the relationship between the approach taken in Barrett and the approach taken in Gorringe there is guidance in paragraph 2 of the judgment of Lord Steyn in the latter case:

"There are . . . a few remarks that I would wish to make about negligence and statutory duties and powers. This is a subject of great complexity and very much an evolving area of the law. No single decision is capable of providing a comprehensive analysis. It is a subject on which intense focus on the particular facts and on the particular statutory background, seen in the context of the contours of our social welfare state, is necessary. On the one hand the courts must not contribute to the creation of a society bent on litigation, which is premised on the illusion that for every misfortune there is a remedy. On the other hand, there are cases where the courts must recognise on principled ground the compelling demands of corrective justice or what has been called "the rule of public policy which has first claim on the loyalty of the law; that wrongs should be remedied": $M$ (A Minor) v Newham London Borough Council and $X$ (Minors) v Bedfordshire County Council [1995] 2 AC 633, at 663, per Sir Thomas Bingham MR. Sometimes cases may not obviously fall in one category or the other. Truly difficult cases arise." 
A further issue relating to reasonableness arises in cases where a person has been running a risk in some relatively normal activity, such as swimming or diving in a lake on land occupied by another person, and he injures himself and sues the occupier on the ground that he should have foreseen the risk of injury and failed to take reasonable care to prevent it. Such a case arose in Tomlinson v Congleton Borough Council [2003] 3 WLR 705. In that case the plaintiff, aged 18, went into a lake and from a standing position in shallow water dived and struck his head on the bottom, breaking his neck. The lake, which had formed in a disused quarry, was in a country park owned and occupied by the defendants, and it attracted many visitors in hot weather. There were attractive sandy banks and in hot weather, many people, including families with children, went there to play in the sand and to sunbathe and paddle in the water. Many prominent notices were displayed reading "dangerous water: no swimming" and the defendants employed rangers to give oral warnings against swimming and to hand out safety leaflets. However the defendants were aware that the notices were frequently ignored and had little effect in stopping swimming and the defendants, aware that several accidents had resulted from swimming in the lake, intended to plant vegetation around the shore to prevent people from going into the water but had not done so because of a shortage of financial resources.

Mr Tomlinson sued the defendants to recover damages for his very severe injuries and one of the questions which arose was whether the risk of the plaintiff injuring himself by diving in the lake was, as provided in section 1(3)(c) of the Occupiers' Liability Act 1984 a risk "against which, in all the circumstances of the case, [the occupier] may reasonably be expected to offer the other [Mr Tomlinson] some protection.". If the risk was such, then section 1(4) imposed a duty to take such care as was reasonable in all the circumstances of the case to see that injury was not suffered by reason of the danger concerned. In the High Court Jack J dismissed the plaintiff's action, but the plaintiff succeeded in an appeal to the Court of Appeal [2003] 2 WLR 1120. In his judgment Ward LJ stated at 1132D:

"Congleton Beach, as the place was also known, was as alluring to "macho" young men as other dangerous places were to young children. In my judgment the gravity of the risk of injury, the frequency with which those using the park came to be exposed to the risk, the failure of warning signs to curtail the extent to which the risk was being run, indeed the very fact that the attractiveness of the beach and the lake acted as a magnet to draw so many into the cooling waters, all that leads me to the conclusion that the occupiers were reasonably to be expected to offer some protection against the risks of entering the water. It follows that in my judgment the defendants were under a duty to the plaintiff."

However, on appeal to the House of Lords the defendants succeeded and the decision of the High Court was restored. In his judgment Lord Hoffmann said at page $720 \mathrm{C}$ :

"I think it will be extremely rare for an occupier of land to be under a duty to prevent people from taking risks which are inherent in the activities they freely choose to undertake upon 
the land. If people want to climb mountains, go hang-gliding or swim or dive in ponds or lakes, that is their affair. Of course the landowner may for his own reasons wish to prohibit such activities. He may think that they are a danger or inconvenience to himself or others. Or he may take a paternalist view and prefer people not to undertake risky activities on his land. He is entitled to impose such conditions, as the Council did by prohibiting swimming. But the law does not require him to do so.

My Lords, as will be clear from what I have just said, I think that there is an important question of freedom at stake. It is unjust that the harmless recreation of responsible parents and children with buckets and spades on the beaches should be prohibited in order to comply with what is thought to be a legal duty to safeguard irresponsible visitors against dangers which are perfectly obvious. The fact that such people take no notice of warnings cannot create a duty to take other steps to protect them."

In his judgment Lord Hobhouse of Woodborough said at page 732B:

"it is not, and should never be, the policy of the law to require the protection of the foolhardy or reckless few to deprive, or interfere with, the enjoyment by the remainder of society of the liberties and amenities to which they are rightly entitled. Does the law require that all trees be cut down because some youths may climb them and fall? Does the law require the coast line and other beauty spots to be lined with warning notices? Does the law require that attractive water side picnic spots be destroyed because of a few foolhardy individuals who choose to ignore warning notices and indulge in activities dangerous only to themselves? The answer to all these questions is, of course, no."

I delivered a judgment concurring in the decision that the appeal should be dismissed and at page 724B I cited the observation of the Lord President, Lord Dunedin, in Hastie v Edinburgh Magistrates [1907] SC 1102, 1106 that there are certain risks against which the law, in accordance with the dictates of common sense, does not give protection - such risks are "just one of the results of the world as we find it".

In conclusion, turning away from the concept of reasonableness in the tort of negligence, I would like to consider the issue of reasonableness in the context of judicial review where a claim is brought, not to recover damages for personal injury, but to set aside the decision of a public or local authority exercising a statutory discretion to which the applicant is opposed. As I have stated, the essence of the principle stated by Lord Greene in the Wednesbury case is that when a local authority has exercised a discretion given to it by Parliament, it is not for the court to sit as a court of appeal and for the judge to substitute his or her view of what is a reasonable exercise of the discretion for the view of the authority. This would be contrary to the intent of Parliament which has entrusted the exercise for the discretion to the local authority and not to a court. The function of the court is to ensure that the authority has not acted in excess of its powers and it would only do this if it 
acted in a manner which was so unreasonable that no reasonable body could have decided so to act. But the court must not go beyond this and in $R \mathrm{v}$ Secretary of State for Trade and Industry Ex parte Lonrho Plc [1989] 1 WLR 525, 535B Lord Keith referred to:

"the danger of judges wrongly though unconsciously substituting their own views for the views of the decision maker who alone is charged and authorised by Parliament to exercise a discretion."

A line of cases where the Wednesbury principle has been applied in Northern Ireland relates to decisions whether or not a parade should be allowed to pass through a particular area or whether conditions should be imposed on those organising or taking part in the parade. The relevant legislation in the past gave power to a senior police officer to impose conditions and such powers are no vested in the Parades Commission. In 1991 the Court of Appeal in Northern Ireland stated the principle as follows in the case of In re Murphy's application [1991] 5 NIJB 88:

"In parts of Northern Ireland and amongst some groups in the community there can be much concern and interest at particular times of the year in the question whether certain processions should be permitted to use particular routes or whether they should be prohibited by the police from using particular routes. It is therefore important that the public should be fully aware of the functions and duties of the courts in relation to such a question. The relevant law has been stated on frequent occasions by the House of Lords, the highest appellate court, in relation to the function of the courts where judicial review is sought in respect of a decision taken by a police officer, or a government minister, or a local authority so some other public body or official, where the making of that decision has been entrusted to him or it by Parliament, under the terms of a statute. The governing principle can be stated in differing terms, but the essence of the principle is that the court does not sit as a Court of Appeal to substitute its opinion of what should be the proper decision for the opinion of the person or body entrusted by Parliament with the making of the decision. The court exercises only a supervisory jurisdiction and not an appellate jurisdiction. This means, in a case such as the present one, that the court will not intervene to set aside the decision unless (the onus of proof being on the applicant) the person making the decision has failed to consider matters which he was bound to consider or included in his consideration matters which were irrelevant or unless the court considers that the person making the decision has abused the exercise of the discretion given to him and has come to a decision to which no reasonable person could have come. There may be arguments of weight and substance on both sides of the matter, but it is not for the court to weigh up the arguments for and against the decision. The weighing of those arguments is a matter for the decision maker, not for the court." 
In recent years there has been some criticism of the Wednesbury principle by that very eminent judge Lord Cooke of Thorndon. In $R$ v Chief Constable of Sussex Ex parte International Trader's Ferry Limited [1999] 2 AC 418, $452 \mathrm{C}$ he said:

"It seems to me unfortunate that Wednesbury and some Wednesbury phrases have become established incantations in the courts of the United Kingdom and beyond. Associated Provincial Picture Houses Ltd v Wednesbury Corporation [1948] 1 KB 223, an apparently briefly-considered case, might well not be decided the same way today; and the judgment of Lord Greene MR twice uses (at pages 230 and 234) the tautologous formula "so unreasonable that no reasonable authority could ever have come to it." Yet judges are entirely accustomed to respecting the proper scope of administrative discretions. In my respectful opinion they do not need to be warned off the course by admonitory circumlocutions. When, in Secretary of State for Education and Science v Tameside Metropolitan Borough Council [1977] AC 1014, the precise meaning of "unreasonably" in an administrative context was crucial to the decision, the five speeches in the House of Lords, the three judgments in the Court of Appeal and the two judgments in the Divisional Court all succeeded in avoiding needless complexity. The simple test used throughout was whether the decision in question was one which a reasonable authority could reach. The converse was described by Lord Diplock, at page 1064, as "conduct which no sensible authority acting with due appreciation of its responsibilities would have decided to adopt." These unexaggerated criteria give the administrator ample and rightful rein, consistently with the constitutional separation of powers."

And in $R$ v Daly [2001] 2 AC 532, 549B he said:

"I think that the day will come when it will be more widely recognised that Associated Provincial Picture Houses Ltd $\mathrm{v}$ Wednesbury Corporation [1948] 1 KB 223 was an unfortunately retrogressive decision in English administrative law, in so far as it suggested that there are degrees of unreasonableness and that only a very extreme degree can bring an administrative decision within the legitimate scope of judicial invalidation. The depth of judicial review and the deference due to administrative discretion vary with the subject matter. It may well be, however, that the law can never be satisfied in any administrative field merely by finding that the decision under review is not capricious or absurd."

No doubt one part of Lord Greene's formulation of the Wednesbury principle was tautologous, but I respectfully consider that it served the useful purpose of emphasising that where a judge is reviewing the lawfulness of an administrative decision it is not for him to substitute his view of what is reasonable for the view of the decision maker. As Lord Lowry stated in $R \mathrm{v}$ Secretary of State for the Home Department Ex parte Brind [1991] 1 AC 696, 
258 Northern Ireland Legal Quarterly [Vol. 55, No. 3]

"what we are accustomed to call Wednesbury unreasonableness is a branch of the abuse, or misuse, of power: the court's duty is not to interfere with a discretion which Parliament has entrusted to a statutory body or an individual but to maintain a check on excesses in the exercise of discretion. That is why it is not enough if a judge fees able to say, like a juror or like a dissenting member of the Cabinet or fellow-councillor, "I think that is unreasonable; that is not what I would have done." It also explains the emphatic language which judges have used in order to drive home the message and the necessity, as judges have seen it, for the act to be unreasonable that no reasonable minister etc. would have done it."

In cases relating to human rights under the European Convention on Human Rights and the Human Rights Act 1998, the principle of proportionality may require a greater intensity of review as stated by Lord Steyn in Daly's case at page 547D. However, in those cases of judicial review where there is no human rights dimension I consider that if the court failed to take into account the distinction between describing an administrative decision as "unreasonable" and describing it as "unreasonable in the Wednesbury sense" there would be a danger that the courts would intrude into the task entrusted by Parliament to administrators and not to judges. 